\title{
INVESTIGATION OF THE RELATIONSHIP BETWEEN RELIABILITY OF TRACK MECHANISM AND MINERAL DUST CONTENT IN ROCKS OF LIGNITE OPEN PITS
}

\section{BADANIE ZWIĄZKU MIĘDZY NIEZAWODNOŚCIĄ PODWOZIA GĄSIENICOWEGO A ZAWARTOŚCIĄ PYŁÓW MINERALNYCH W SKAŁACH KOPALNI ODKRYWKOWYCH WĘGLA BRUNATNEGO}

\begin{abstract}
This paper describes a mathematical relation which is developed to estimate the occurrence of track mechanism failure in function on the mineral dust $\left(\mathrm{SiO}_{2}\right)$ content, i.e. wear intensity. This relation is based on actual data of track-type machine (bulldozers) failures, the properties of rocks and measurements of wear intensity on the upper rollers of track mechanism. Failures of bulldozers were recorded during the period of 12 months on six open pits in Serbia, together with their location which is correlated rock type and $\mathrm{SiO}_{2}$ content. This enabled establishment of the reliability indicators using two-parameter Weibull distribution. Further on, correlation is interpreted based on the linearization model using the method of least square. This research has impact on proper management of track-type machines operating on lignite open pits, in the sense of predicting time to failures and cost of maintenance of these machines. This approach provided guidelines for the establishment of reliability centered maintenance model.
\end{abstract}

Keywords: maintenance engineering, reliability function, abrasive wear, mineral dust, bulldozer, track mechanism

\begin{abstract}
Artykut opisuje relację matematyczna, która pozwala oszacować czas do wystapienia uszkodzenia podwozia gasienicowego w funkcji zawartości pylu mineralnego (SiO2), czyli intensywności zużycia. Relacja ta została oparta na rzeczywistych danych o uszkodzeniach maszyn gasienicowych (spycharek) $i$ właściwościach skał oraz na pomiarach intensywności zużcia rolek podtrzymujacych (górnych) podwozia gasienicowego. Uszkodzenia koparek rejestrowano przez okres 12 miesięcy w sześciu kopalniach odkrywkowych w Serbii. Obserwacje prowadzono w kopalniach o lokalizacji podobnej pod względem wystęujących typów skat i zawartości SiO2. Pozwoliło to na wyznaczenie wskaźników niezawodności przy pomocy dwuparametrycznego rozkładu Weibulla. Omawiana korelację interpretowano na podstawie modelu liniowego z zastosowaniem metody najmniejszych kwadratów. Przedstawione badania maja znaczenie dla właściwego zarzadzania maszynami gasienicowymi pracujacymi w kopalniach odkrywkowych węgla brunatnego, jako że pozwalaja na przewidywanie czasu do uszkodzenia oraz kosztów utrzymania tych maszyn. Prezentowana metoda zawiera wytyczne do opracowania niezawodnościowego modelu utrzymania ruchu.
\end{abstract}

Stowa kluczowe: inżynieria utrzymania ruchu, funkcja niezawodności, ścieranie, pył mineralny, spychacz, podwozie gasienicowe.

\section{Introduction}

Reliability is a concept that is the most written in the systems sciences for the maintenance engineering and development of quality of service in industry in general. With the beginning of systems' sciences development, practically after the World War II, reliability engineering as a concept of technical systems' assessment had the most progressive development. Development of reliability theory paralleled with development of soft computing and theory of probability. Scientific investigations are moving in several directions. Some of them will be mentioned bellow. In many articles is written about correlation between reliability and maintenance policy [5, 25], in terms of determining optimal maintenance action intervals in dependence of reliability [17], i.e. in terms of Reliability Centered Maintenance (RCM) [9, 30], in terms of reducing the maintenance costs and improve the effectiveness of the maintenance activities [3,9], in terms of investigation of dependence between reliability and phenomena such as fatigue [21, 23], corrosion [5] and so on, or in terms of reliability based design of machine [1]. RCM is a systematic analysis method for planning the preventive maintenance of technical systems. RCM is used to develop scheduled maintenance plans that will provide an acceptable level of availability and dependability, considering to acceptable level of risk, in an efficient and cost-effective manner [15]. This approach was also introduced into SAE JA1012 standard. RCM is most commonly used for prediction of preventive action and spare parts stocks, depending on the cost [9]. There is no general recommendation in the level of reliability to perform preventive replacement. Every engineering system is a special case.

Mining equipment is a key element of mining production. Mining equipment complexity and dimension are continually increasing. Unplanned failures of mining equipment cause higher repair and replacement costs. On the other side, lost production costs are even more important. Risk for environmental and workers are also high. Those facts emphasize the importance of a reliability analysis into the operation of mining equipment $[2,3,21,24]$. In [24] says that reliability function is the basis of reliability investigations and he goes to perform a comparative analysis of twenty studies dealing with the mining equipment reliability, which highlight the importance of reliability research especially in the mining industry.

Track-type machines are very often used in mines. Undercarriage expense can be a major portion of the operation costs for track-type machines. The upper structure of the machine can be in great position 
and the undercarriage is completely wasted, in the same time. Because of that, reliability of undercarriage is most important for systematic analyze, among the parts of track-type machines. Major equipment manufacturers identified five primary conditions affecting probable life-expectancy of track-type undercarriage: impact, abrasiveness i.e. wear, terrain structure, operation and maintenance, as mentioned in Caterpillar's Performance Handbook Ed. 43. It is evident that all of these effects can be monitored and even avoided, except abrasiveness.

One of the important process which is causing reduced reliability of machines in mining industry is wear. Reason is contact of cutting elements and the working environment [13] or contact of transport mechanisms and the soil [8] that contains abrasive elements (sand with quartz $-\mathrm{SiO}_{2}$ ). Issue of abrasion, $\mathrm{SiO}_{2}$ content and wear was a research topic by several authors in the past. Cerchar test [4] and Cerchar Abrasiveness Index (CAI) are commonly used for assessment of rock abrasivity worldwide [18]. This test and derived index are used to estimate wear of cutting picks and associated replacement cost during rock excavation. Another research suggested that quartz content is most important rock property influencing the wear of cutting tools [27]. Research performed for coal measures rocks confirmed correlation, i.e. linear relationship between abrasiveness and average quartz grain size [28].

However, relation between wear caused by $\mathrm{SiO}_{2}$ content in the rocks and remaining capabilities of mechanical equipment was not examined-researched in detail.

In any case, it is important that determining parameters of reliability are accompanied with defining the precise engineering conclusions which will contribute to advance quality of service of technical systems. The idea of this article is to find explicit correlation between reliability parameters and wear intensity parameters, in order to predict timeline of replacement of upper roller on bulldozer track mechanism and avoid unplanned down-time. Bulldozers are one of the most important machines of auxiliary machinery at lignite open pit mines. In terms of quality management of the mine, it is very important to be able to predict the moment when the machines should undergo the repair. Therefore, this article provides mathematical model and procedure which can be used to improve maintenance policy design and to reduce operational costs, according to principle of RCM.

\section{Wear and problems with track mechanism and upper roller}

Maximum effects of mining mechanization operating at open pit mines are obtained through timely and quality performing of the auxiliary works. For these operations to be performed, open pit must have a sufficient number of respective auxiliary machines, primarily bulldozers. They operate in extremely difficult conditions on spoil levels of open pits, within extremely variable operation conditions, from maximum drive to the transportation conditions. For these reasons, life time of these machines at open pits is relatively short and usually lasts for several years. Their reliability declines rapidly while exploitation and maintenance costs grow rapidly. For these reasons it is necessary to continuously monitor the indicators of dependability of these machines [22]. In the first place this refers to weak points on bulldozers. One of these weak points is upper roller assembly at track mechanism (Figure 1). Upper roller is exposed to the process of wear from the soil on which bulldozer moves. As the percentage of abrasive components in material is higher, so is the roller wear more intense.

Moderate wear of material on the surface is considered to be normal occurrence. However, in many cases wear is increased or abnormally high with significant surface damage of softer material in contact [10]. Such wear in relatively short period of time leads to cancellation and cracking of elements, and thus breakage of machines. This is the case with the upper rolls on bulldozers analyzed in this pa- per. Abrasive wear of the upper rolls on bulldozer is a distinctive type of wear. Working conditions of bulldozers in lignite open pit mines in Serbia are different depending on the input of abrasive contaminants. These contaminants, depending on the type of exploited mineral resource, can have very different composition. The main ingredient is typically sand with quartz.

Wear monitoring techniques [6] are based on noise detection during regular operation, increased vibrations, detection of infrared radiation caused by friction, visualization of contact surface with high resolution cameras. In general, these techniques are supported by tribology system which contains greasing system or other cooling system. There is no greasing system of the upper roller assembly of the bulldozer. However, above mentioned techniques are relevant in numerous situations, especially in laboratory conditions. On-site measurement of such tribo-mechanical system, as described in this paper, is hindered by few circumstances. First, it is very difficult to detect noise emitted by this tribo-mechanical system during regular operation of the bulldozer due to significant background noise emitted in its vicinity by noisier components (such as engine, as well as technological process). Secondly, vibration measurement requires accurate positioning of probes, which is impossible in case of upper roller due to large dynamic loading and impacts. Thirdly, heat sensing with infra-red camera can't be applied because of dust and dirt deposits on the surface of this tribo-mechanical system (acquired data would not be accurate since heat emission varies depending from the amount of dirt and dust deposits). Finally, visualization of contact surface with high resolution camera is mainly used in controlled conditions, such as laboratory, i.e. without dust, and in case of upper roller this can't be achieved. It is obvious that these techniques are providing more reliable determination of condition and behavior of a tribo-mechanical system. However, in case of upper roller on bulldozer these techniques are not applicable, and application of measuring tools is still an optimal method for measurement of wearing. Therefore, it makes sense to monitor the statistical data, and processing based on reliability theory.

Layout of machine TD25M bulldozer with details of upper roller is presented on Figure 1, as provided by the Dressta, manufacturer of bulldozer. Figure 1.a presents the position of the upper roller of track mechanism. Figure 1.b presents photo of the new upper roller, and Figure 1.c presents the cross-section and dimensions of the upper roller with the wear area. Figure 1.c presents photo of the upper roller on the spot, namely in operation. During the operation it has been observed that the wear (figure1.c) is more intense when the machine is running on the soils that have higher percentage of sand, in the surface layer.

Abrasive wearing is most frequently deterioration-removal of metal due to presence of $\mathrm{SiO}_{2}$ particles between mating surfaces. In this case these surfaces are track wearing plate and upper roller. Size of particles is between 150 and $200 \mu \mathrm{m}$. There is no lubricant between two metal surfaces, while the concentration of abrasive material (sand - $\mathrm{SiO}_{2}$ ) is high. Therefore, this mechanism has no adhesive wearing, but solely abrasive wearing. Basic abrasive process is shown on Figure 2. Figure 2 shows detail of the upper roller with theoretical interpretation of abrasion occurring between wheel and tracked plat. This process is showed for two situations: beginning of wearing and wear after 700 operating hours. A reduced thickness of hardened zone is evident, as well as increased roughness.

Wearing diagram i.e. relation between wearing intensity and time in operation, for Drmno, Tamnava Zapad and Veliki Crljeni open pits is shown on Figure 3, as well as quartz content $\left(\mathrm{SiO}_{2}\right)$ in rocks of these open pits. Multiple measurements were performed by Vernier gauge on several locations of roller diameter and average value was used for wearing diagram. It is obvious that wearing intensifies after 1205, 1880 and 2242 operating hours for respective open pits. Increase is caused by hardness zone wearing off. Therefore, these times could 
be considered as times for upper roller replacement as a preventive measure.

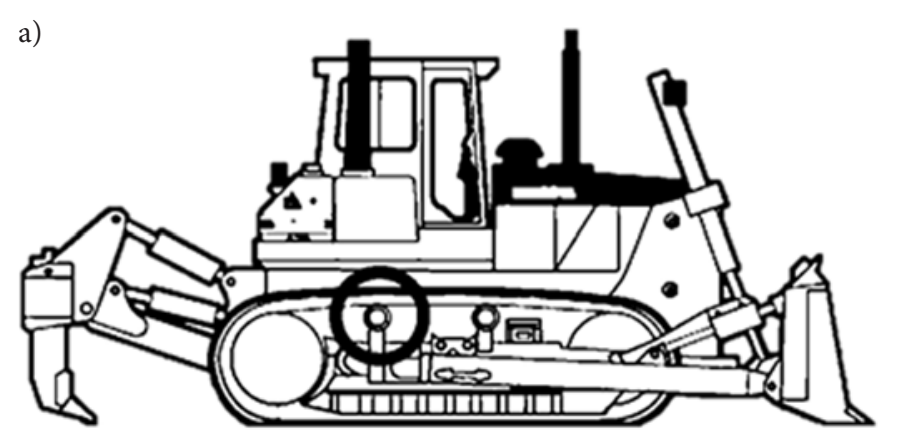

b)

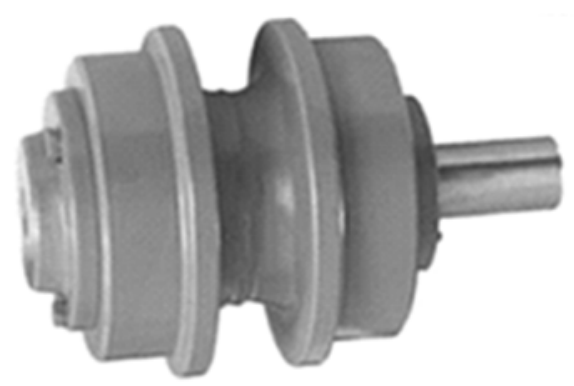

c)

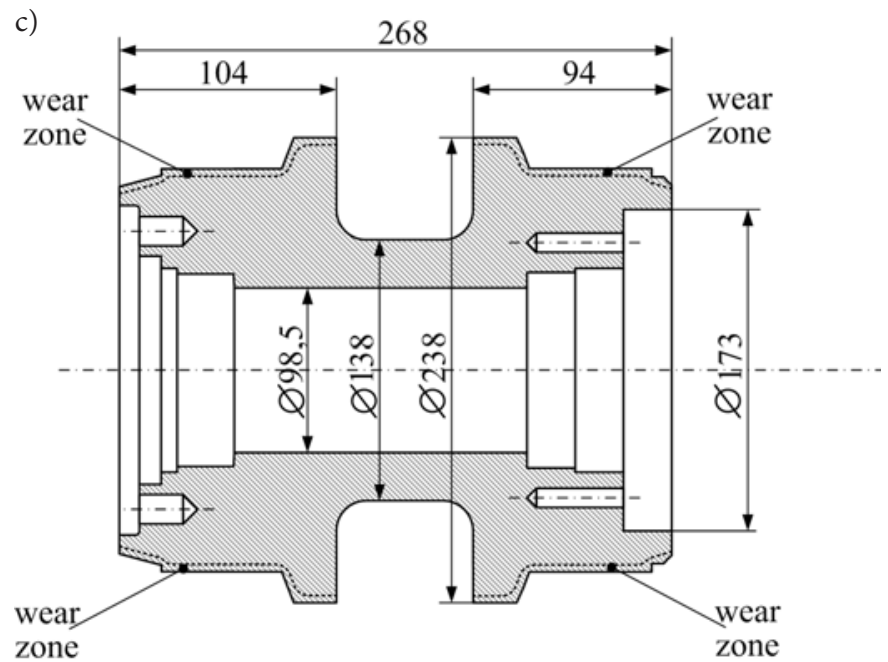

b)

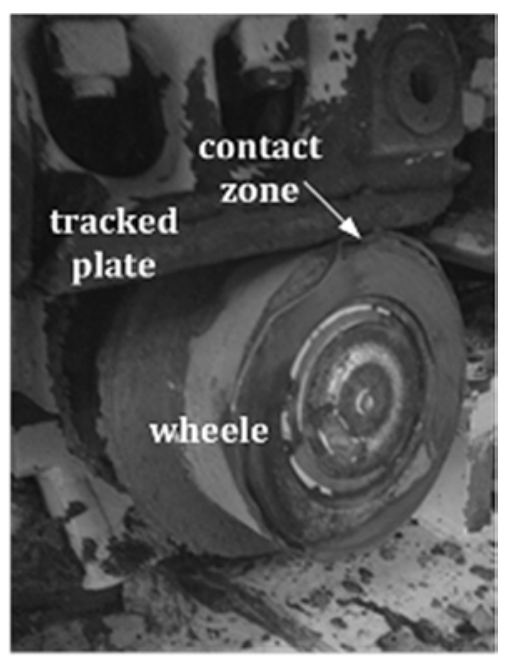

Fig. 1. a. Layout of bulldozer, position of upper roller at track mechanism of bulldozers b. Photo of new upper roll c. Dimension of upper roll $d$. Photo of upper roll in operation

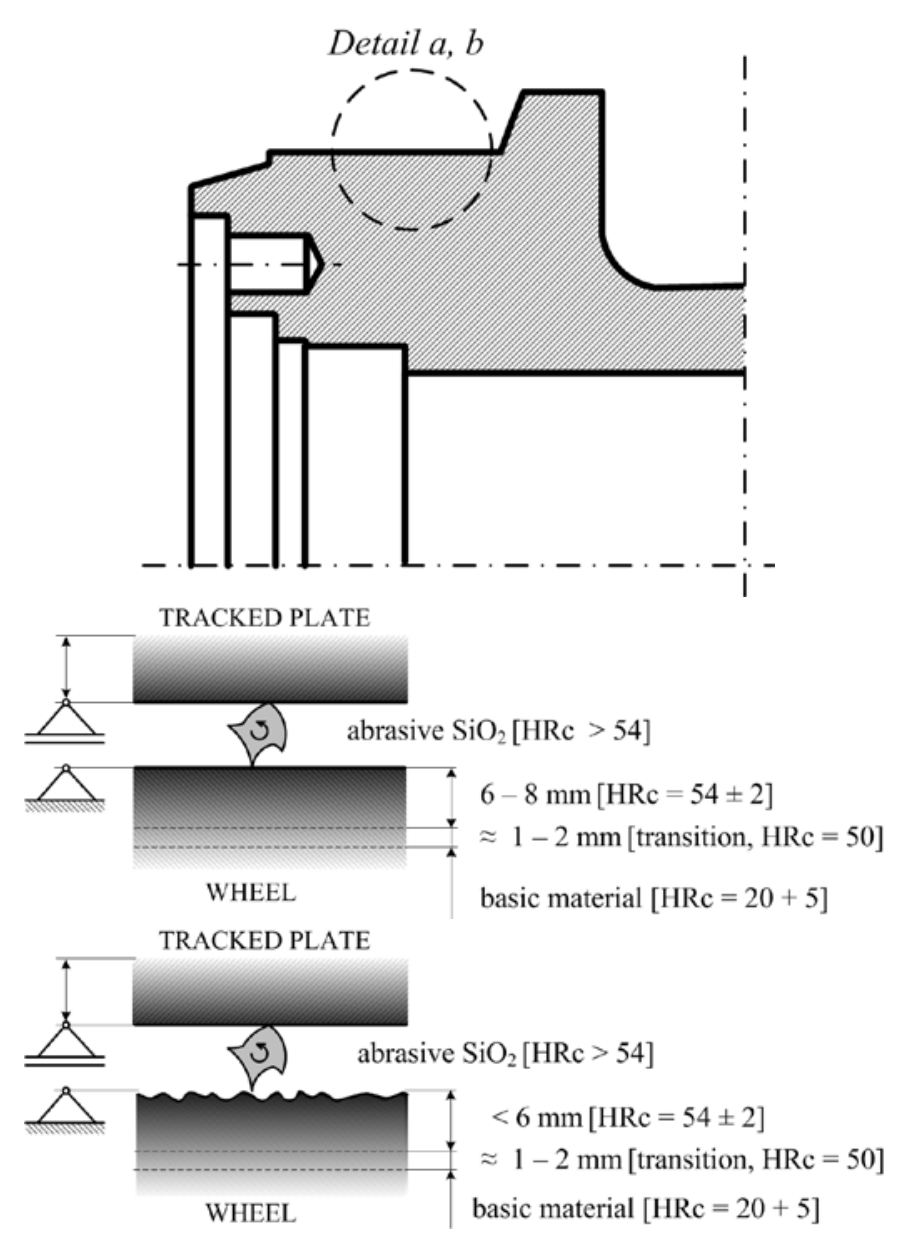

Fig. 2. The process of abrasive wear of the dozer upper roller TD25M

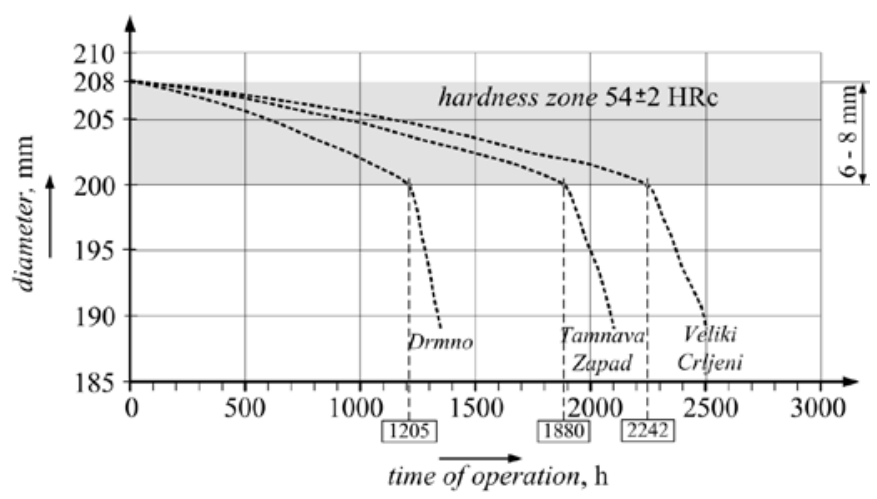

Fig. 3. Diagram of wear of dozer upper roller TD25M

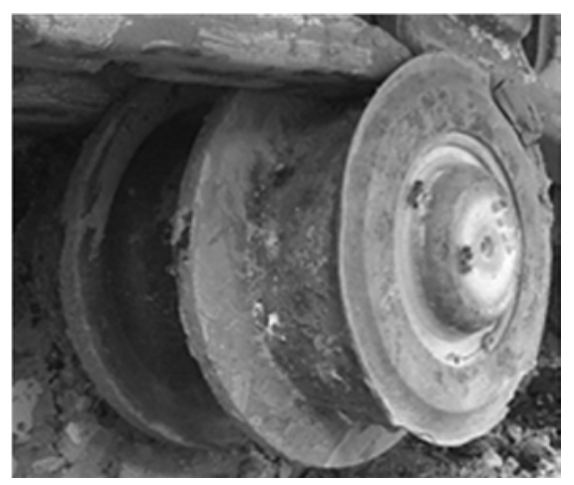

Fig. 4. [Part 1] 


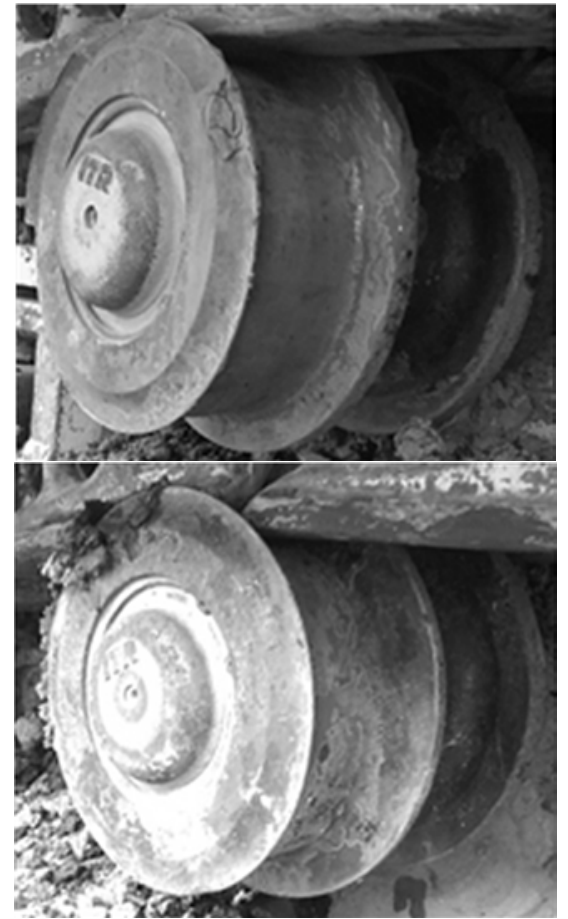

Fig. 4. Upper rollers of bulldozer TD-25M on the open pits Drmno, Tamnava Zapad and Veliki Crljeni after 1205, 1880 and 2242 hours in operation respectively

\section{Analysis of two-parameter Weibull distribution and application in reliability engineering}

Reliability characteristics of observed technical systems are determined on the basis of empirical data about Time To Failure (TTF). This data is collected during observing of systems during operation or experiment. One of the tasks for reliability analysis is to determine what theoretical distribution might be suitable for the best interpretation of the collected empirical data. In probability theory and statistic, it is developed dozens of distribution laws. Swedish engineer, scientist, and mathematician Ernst Hjalmar Waloddi Weibull (1877-1979), in 1939 published an article in which he described the Weibull distribution. Due to its parametric nature, this distribution was proved to be suitable for presenting large number of phenomena. It can also successfully interpret phenomena which can be presented trough some other distribution (Exponential, Rayleigh, Normal) [26]. The Weibull distribution is an important distribution especially for reliability and maintainability analysis. In article [21] on the base of the two-parameter Weibull distribution, authors were calculate mathematical correlation between conveyor rubber belt failures rate function and belt length. Authors proved trough reliability monitoring, that larger number of bending per unit length, i.e. increased fatigue loading, reduces operational life of the rubber belt. It should be noted that number of belt's bending is larger with shorter belts-conveyors. Dependence between mean time to failure and belt length is linear character. In [24] Exponential, Lognormal, Normal and Weibull distribution law, were used for analyze of draglines' mechanical failures. According to Kolmogorov-Smirnov statistical test, shows that empirical data to be best modeling with Weibull distribution. In articles [7, 29] authors suggests that the Weibull distribution is commonly used to model and analyze the failure data and lifetime data in general.

\subsection{Definition of reliability function}

Reliability function, on the base of two parameters Weibull distribution is written as $[14,16]$ :

$$
R(t)=e^{-\left(\frac{t}{\eta}\right)^{\beta}}
$$

where $\beta$ is shape and $\eta$ is scale parameter.

Dependence between parameter $\beta$ and $R(t)$ is quite evident (Figure 5). For the cases when $0.5 \leq \beta \leq 1.5$ Weibull distribution is inclined to Exponential distribution, while when $2.5 \leq \beta \leq 5$ Weibull distribution is inclined to Normal distribution $[14,16]$.

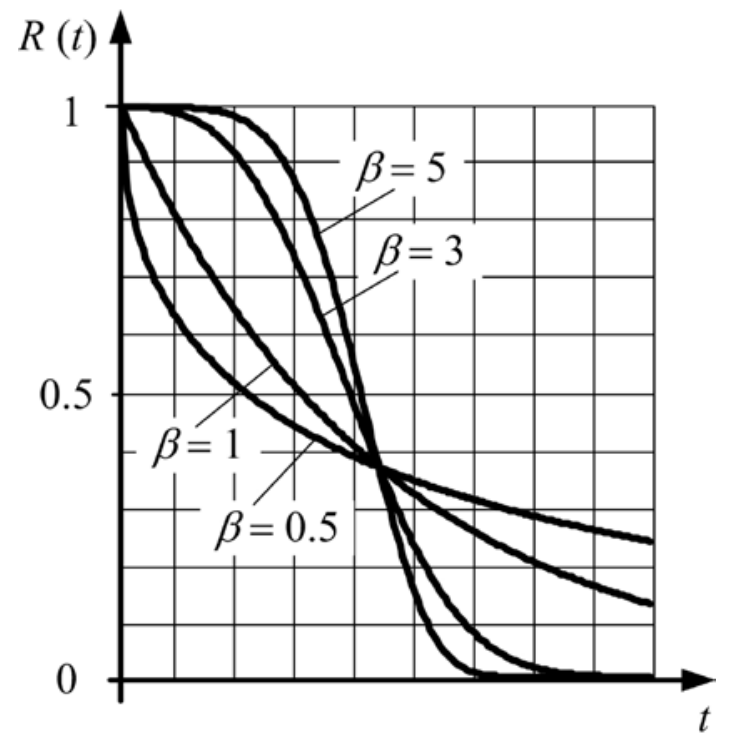

Fig. 5. Reliability function $R(t)$ and shape parameter $\beta$

The two parameter Weibull cumulative distribution function [14, 16], i.e. probability of failure at time is defined as:

$$
R(t)+F(t)=1 \Rightarrow F(t)=1-R(t)=1-e^{-\left(\frac{t}{\eta}\right)^{\beta}}
$$

The mean time could be calculated as:

$$
\bar{T}=\eta \cdot \Gamma\left(1+\frac{1}{\beta}\right)
$$

where $\Gamma$ is gamma function: $\Gamma(p)=\int_{0}^{\infty} t^{p-1} e^{-t} d t$ and $p=1+\frac{1}{\beta}$.

Gamma function is not easy for calculate and usually is given in appropriate tables [16].

\subsection{Procedure for determination of reliability function}

Procedure for determination of reliability function on the base of the two-parameter Weibull distribution, consist of next steps: data collection and ranking, data entry in Weibull Plotting Paper (WPP) [14], assessment of distribution parameters and testing of hypothesis for distribution law. Data for the analysis are periods until the failures up times, apropos the times that the system correctly operates. In real conditions this step is very complicated because there is no existing quality system for detection of failures and their correct recording. Usually, small number of data is available. In cases where the number of data is $n 30$, median rank (MR) also known as Bernard's approximation, is used instead of empirical cumulative distribution function $F(t)[16]$ : 


$$
M R=\frac{i-0.3}{n+0.4}
$$

where $i=1 \ldots n$ is rank number of the data.

Mean rank and Symmetrical cumulative distribution function did not find a significant place in reliability engineering.

WPP (Figure 5) [14], has axes that transform the cumulative probability distribution function into straight line. If the data that is plotted on this type of paper forming straight line, it means that hypothesis is proper. WPP can simply be created. The Weibull distribution is defined as (1) and (2). This can be written as:

$$
\frac{1}{1-F(t)}=e^{-\left(\frac{t}{\eta}\right)^{\beta}}
$$

Taking two times the natural logarithms ( $\ln l n)$ of both sides gives an equation of a straight line:

$$
\ln \ln \left(\frac{1}{1-F(t)}\right)=\beta \cdot \ln (t)-\beta \cdot \ln (\eta)
$$

This equation is a straight line $y=a \cdot x+b$ on coordinate system with ordinate axis: $y=\ln \ln \left(\frac{1}{1-F(t)}\right)$ versus abscissa axis: $\underline{x}=\ln (t)$. If at WPP entered points with coordinates $F(t)$ and $t$, they should be approximated with straight line. The slope of the straight line in this plot is the shape parameter $\beta$. Values of $t$ for point on line with coordinate $F(t)=0.63212$, is scale parameter $\eta$. It is known that: $\ln \ln \left(\frac{1}{1-0.63212}\right)=0$.

There are several analytical methods used in estimating Weibull parameters [12]. Least Squares Method (LSM) is commonly applied in engineering and mathematics problems. According to this method, can be written:

$$
a \cdot \sum_{i=1}^{n} x_{i}^{2}+b \cdot \sum_{i=1}^{n} x_{i}=\sum_{i=1}^{n} x_{i} \cdot y_{i} ; a \cdot \sum_{i=1}^{n} x_{i}+n \cdot b=\sum_{i=1}^{n} y_{i}
$$

Solving the system of equations is obtained:

$$
\mathrm{a}=\beta ; b=-\beta \cdot \ln (\eta) \Rightarrow \eta=\mathrm{e}^{-\left(\frac{b}{a}\right)}
$$

The Kolmogorov-Smirnov test ( $\mathrm{K}-\mathrm{S}$ test) is the most common method for testing of hypothesis of established distribution law. K-S test has been used to decide if the failure data comes from a population with a specific distribution. $\mathrm{K}-\mathrm{S}$ test compare empirical cumulative distribution function and theoretical function $F(t)$, on the base of their distance $D_{n}$. Necessity is that the distance is less than the critical value $D_{n \alpha}$, and we can conclude that the data is a good fit with the specified distribution law. Critical value can be found in the Kolmogorov-Smirnov Table [14, 16].

Probability that the observed data would follow by specified theoretical law, can be defined in dependence of significance level $(\alpha)$ :

$$
P\left(D_{n} \leq D_{n \alpha}\right)=1-\alpha
$$

\section{Implementation of two-parameter Weibull distribu- tion for determination of reliability of track-type mechanism of bulldozers and relationship between reliability parameters and share of mineral dust}

Kostolac and Kolubara are major surface mines in Serbia, producing lignite in following open pits: Drmno and Ćirikovac (Kostolac) and Tamnava Zapad, Polje D, Polje B, Veliki Crljeni (Kolubara). Kostolac and Kolubara mines are operating as a part of the Electric Power Industry of Serbia (EPS) [11]. As reported in EPS internal documents, more than 700 auxiliary machines are operating in these open pits. These machines are very important for the unhampered execution of core operation, and any unplanned absence of machines can cause enormous costs. Among the auxiliary machinery, bulldozers are certainly the most important and it is therefore necessary to monitor the reliability and maintainability of these machines [6]. There are more than 120 bulldozers within Electric Power Industry of Serbia.

Mineralogy analyses of rocks in mentioned open pits were performed for each pit separately and provided in respective mining iand geological documents - Elaborate on reserves [19, 20]. Elaborate on reserves are in fact Governmental records on the amount and properties of mineral resources, and as such are available on each individual mine. After reviewing these documents it was possible to identify rocks with significant content of mineral dust-sand, for each open pit:

1. Kostolac „Drmno”- sandy sediment $-85 \%$

2. Kostolac "Ćirikovac" - sandy clayey sediment $-54 \%$

3. Kolubara "Tamnava zapad" - clayey sandy sediment (siltstone) $-41 \%$

4. Kolubara "Polje D" - clayey sandy sediment (siltstone) $40 \%$

5. Kolubara "Veliki Crljeni" - clay type sediment - 14\%

6. Kolubara "Polje B" - clayey sandy sediment (siltstone) $38 \%$

On the mentioned open pit mines were noted time to failures (TTF) in relation to failures of upper roller (Table 1).The first mentioned open pit Drmno is being observed. Number of data is $n=10$, namely $n<30$, therefore the median rank method (equation 4 ) is used for determining the cumulative distribution function $F(t)$. Points that represent given times in Table 1 and corresponding MR are then drawn into WPP (Figure 3), and the straight line is drawn so that it best approximates the given points. According to the plotting paper it can be seen that the assumption about the Weibull distribution is correct. Coordinates of specified points (Table 2, column 1) in accordance with WPP are given in Table 2 (column 2 and 3).

It should be mentioned that main goal of this research was to analyze failures of identical components (upper roller of Dressta TD$25 \mathrm{M}$ bulldozer) in different operating conditions $\left(\mathrm{SiO}_{2}\right.$ content), and consequence of this approach is a small sample, which is a common situation in mining engineering. Uzgoren et al. are stating „The primary problem with the data was the lack of information" in their effort of promoting the reliability theory in real conditions of mining industry [24]. It is simply impossible to stop the production system in order to analyze individual machines for experimental research. Therefore, data on TTF, collected at lignite open cast mines of Electric Power Industry of Serbia, in presented case study must be processed by MR method, i.e. approximated with Bernard's approximation (equation 4). Furthermore, only realistic approach was to collect the data for identical machines operating in different conditions-open cast mines during the period of one year (Table 1).

Using the LSM (equation 7) the equation of the straight line from WPP is obtained (Table 2, column 4-7), namely the values of shape parameter $(\beta)$ and scale parameter $(\eta)$ of the two-parameter Weibull distribution (equation 8): 
Table 1. Time to failures (TTF)

\begin{tabular}{|c|c|c|c|c|c|c||}
\hline \multirow{2}{*}{$\mathrm{i}$} & Drmno & Ćirikovac & $\begin{array}{c}\text { Tamnava } \\
\text { Zapad }\end{array}$ & Polje D & Polje B & $\begin{array}{c}\text { Veliki } \\
\text { Crljeni }\end{array}$ \\
\cline { 2 - 7 } & \multicolumn{7}{|c||}{ TTF, hours } \\
\hline 1 & 812 & 1172 & 1522 & 1530 & 1606 & 1986 \\
\hline 2 & 1082 & 1621 & 1898 & 1892 & 1958 & 2297 \\
\hline 3 & 1102 & 1783 & 2000 & 2063 & 2077 & 2464 \\
\hline 4 & 1297 & 1848 & 2053 & 2088 & 2202 & 2601 \\
\hline 5 & 1356 & 2012 & 2086 & 2118 & 2401 & 2903 \\
\hline 6 & 1382 & 2425 & 2182 & 2251 & 2763 & \\
\hline 7 & 1437 & & 2307 & 2392 & & \\
\hline 8 & 1521 & & 2588 & 2689 & & \\
\hline 9 & 1688 & & & & & \\
\hline 10 & 1820 & & & & & \\
\hline
\end{tabular}

Table 2.Procedure for obtaining of reliability function for "Drmno Open Pit Mine"

\begin{tabular}{|c|c|c|c|c|c|c|c|c|}
\hline 1 & 2 & 3 & 4 & 5 & 6 & 7 & 8 & 9 \\
\hline$i$ & $\mathrm{TTF}=t$ & $\mathrm{MR}=F(t)$ & $\ln (t)=x$ & $y=\ln \ln \left(\frac{1}{1-F(t)}\right)=y$ & $x^{2}$ & $x \cdot y$ & $F(t)_{\text {teor. }}$ & $D$ \\
\hline 1 & 812 & 0.06731 & 6.69950 & -2.66384 & 44.88330 & -17.84642 & 0.05987 & 0.00743 \\
\hline 2 & 1082 & 0.16346 & 6.98657 & -1.72326 & 48.81211 & -12.03969 & 0.21018 & 0.04672 \\
\hline 3 & 1102 & 0.25962 & 7.00488 & -1.20202 & 49.06837 & -8.42003 & 0.22665 & 0.03296 \\
\hline 4 & 1297 & 0.35577 & 7.16781 & -0.82167 & 51.37749 & -5.88955 & 0.42311 & 0.06734 \\
\hline 5 & 1356 & 0.45192 & 7.21229 & -0.50860 & 52.01719 & -3.66814 & 0.49193 & 0.04001 \\
\hline 6 & 1382 & 0.54808 & 7.23129 & -0.23037 & 52.29151 & -1.66584 & 0.52286 & 0.02522 \\
\hline 7 & 1437 & 0.64423 & 7.27031 & 0.03292 & 52.85745 & 0.23937 & 0.58848 & 0.05576 \\
\hline 8 & 1521 & 0.74038 & 7.32712 & 0.29903 & 53.68674 & 2.19105 & 0.68578 & 0.05460 \\
\hline 9 & 1688 & 0.83654 & 7.43130 & 0.59398 & 55.22421 & 4.41402 & 0.84789 & 0.01135 \\
\hline 10 & 1820 & 0.93269 & 7.50659 & 0.99269 & 56.34892 & 7.45171 & 0.93121 & 0.00148 \\
\hline \multicolumn{3}{|r|}{$\Sigma=$} & 71.83767 & -5.23113 & 516.56730 & -35.23351 & & \\
\hline
\end{tabular}

$a \cdot x^{2}+b \cdot x=x \cdot y$

$a \cdot 516.56730+b \cdot 71.83767=-35.23351$

$a \cdot x+b \cdot n=y$

$a \cdot 71.83767+b \cdot 10=-5.23113$

$a=4.67=\beta$

$b=-34,07392=-\beta \cdot \ln (\eta) \Rightarrow \eta=1474,06$ hours.

Finally, we get reliability function $R(t)$ (equation 1 ) and mean time between failures MTTF (equation 3), for the presented case:

$R(t)=e^{-\left(\frac{t}{\eta}\right)^{\beta}}=e^{-\left(\frac{t}{1474,06}\right)^{4,67}}$

MTTF $=\eta \cdot \Gamma\left(1+\frac{1}{\beta}\right)=1474.06 \cdot \Gamma\left(1+\frac{1}{4,67}\right)=1474.06 \cdot \Gamma(1,21412)=1348.13$ hours.

Maximum difference between empirical (Table 2 - column 3) and theoretical (Table 2 - column 8) value of function $F(t)$, is for data $i=4$ :

$\operatorname{MR}(i=4)=0,35577$
$F(1297)_{\text {teor. }}=1-e^{-\left(\frac{1297}{1474.06}\right)^{4.67}}=0.42311$
$D_{n(i=4)}=\left|F(1297)-F(1297)_{\text {teor. }}\right|=|0.35577-0.42311|=0.06734$

For the given example that contains $n=10$ data, according to K-S test for goodness of fit (equation 9), the acceptable difference between empirical and theoretical value is:

$D_{n ; \alpha}=D_{10 ; 0,05}=0.410$

Usually calculated with level of significance $\alpha=0.05$; i.e. confidence $95 \%$ (equation 9 ).

Since $D_{n}=0.067<0.410=D_{10,0.05}$, we conclude that the data is a good fit with the Weibull distribution.

At the same way, count $R(t)$ and MTTF for others mines. This paper will present only the results - Table 3 . On the 


$$
R_{V . \text { Crljeni }}=\mathrm{e}^{-\left(\frac{2242}{2600.09}\right)^{7.29}}=71 \%
$$

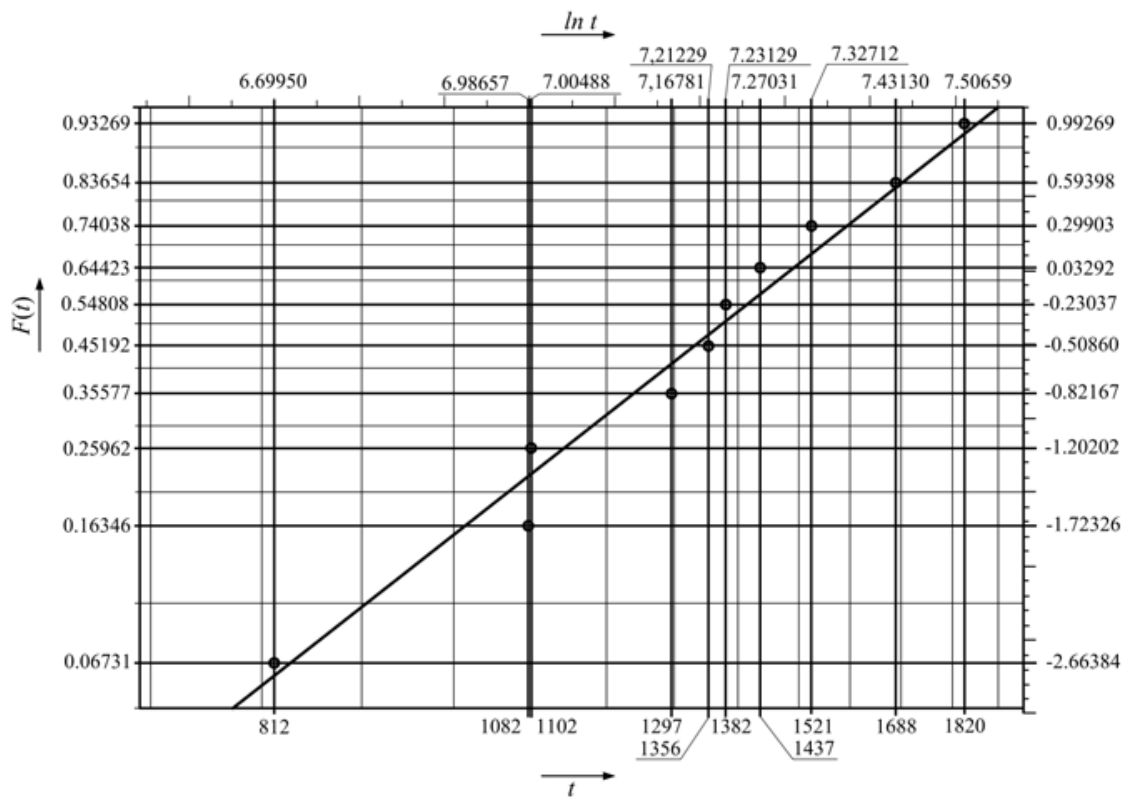

Fig. 5. Weibull plotting paper
There is an obvious correlation between measurements and calculated reliability function. At the time of increased wearing occurrence, reliability is approximately $70 \%$. This conclusion can be used for selection of upper roller replacement moment, in order to avoid unexpected failures.

In this article RCM model of bulldozer is set on the base of wear of the undercarriage of the machine. It is necessary to find right moment for maintenance actions, in this case replacement of worn parts with new spare parts. On the Figure 8, it can see dependence be-
tween mean time to failure MTTF and sand percent. From Figure 8 it is evident linear dependence between MTTF and sand percent. Using the LSM (equation 7) for $n=6$ (Table 4), can be obtained and the mathematical relationship between these values in the form:

$a \cdot x^{2}+b \cdot x=x \cdot y$

$a \cdot 24487958.38+b \cdot 11947.41=498263.10$

$a \cdot x+b \cdot n=y$

$a \cdot 11947.41+b \cdot 6=272$

$a=-0.06212$

$b=169.03227$

MTTF $=\frac{S-b}{a}=\frac{S-169.03227}{-0.06212}$

$M T T F=2720.98-16.10 \cdot \mathrm{S}$

Table 3. Reliability function and Mean time to failure for analyzed mines

\begin{tabular}{||c|c|c|c||}
\hline & Drmno & Ćirikovac & Tamnava Zapad \\
\hline MTTF $=$ & $e^{-\left(\frac{t}{1474.06}\right)^{4.67}}$ & $e^{-\left(\frac{t}{1987.21}\right)^{4.28}}$ & $e^{-\left(\frac{t}{2218.10}\right)^{6.88}}$ \\
\hline & 1348.13 & 1808,36 & 2073.02 \\
\hline Polje D & $e^{-\left(\frac{t}{2278.39}\right)^{6.41}}$ & $e^{-\left(\frac{t}{2334.46}\right)^{5.68}}$ & $e^{-\left(\frac{t}{2600.09}\right)^{7.29}}$ \\
\hline MTTF $=$ & 2121.40 & 2159.16 & 2437.37 \\
\hline \hline
\end{tabular}

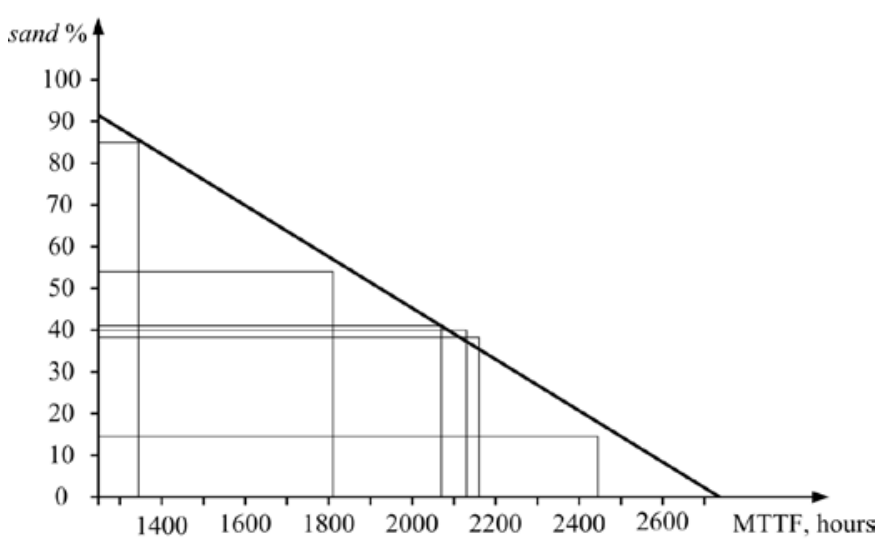

Fig. 7. Dependence between mean time to failure and sand percentage in soil

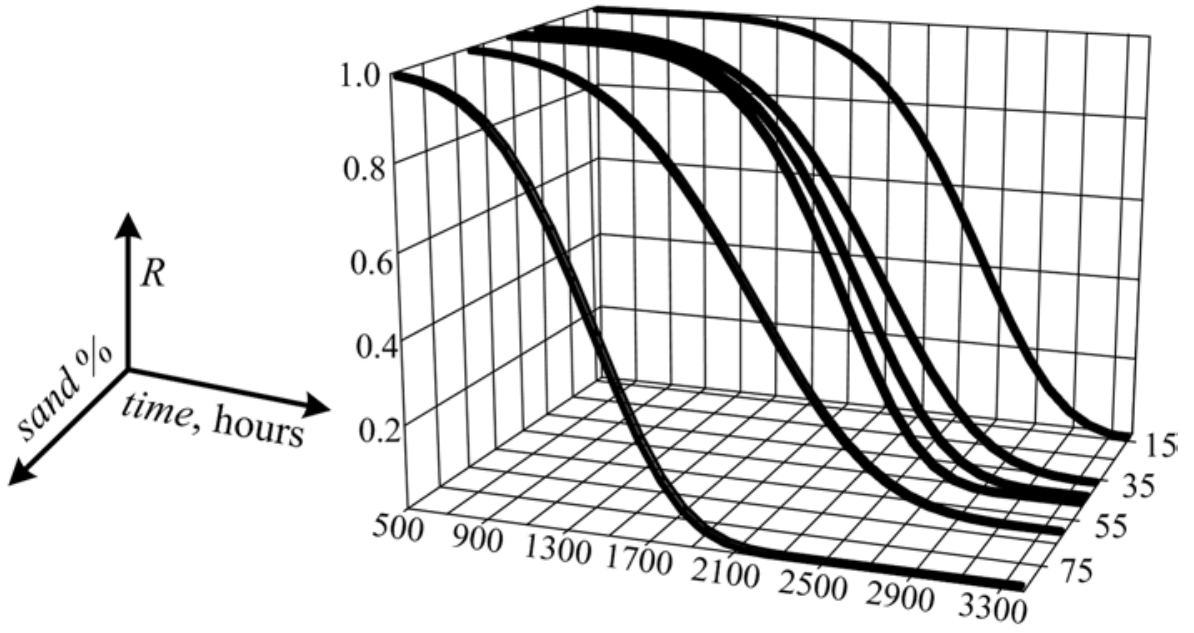

Fig. 6. Reliability function $R$ in dependence of time and sand percent where $S=$ sand $\%$

The largest difference between the empirical and theoretical dependence function MTTF i sand $\%$ is for data $i=6$ (Table $4-$ column 7), where it is around $2.5 \%$. It can be considered that the high accuracy of the assumption.

Presented research was performed on six different open pits on same machine-bulldozer, and it was related to reliability and wear process. Main result is ability to identify the moment (MTTF - Eq. 10) of bulldozer failure, depending on the content of sand $\left(\mathrm{SiO}_{2}\right)$ in the soil. 
Table 4. Procedure for obtaining of correlation between MTTF and sand percent

\begin{tabular}{|c|c|c|c|c|c|c|}
\hline 1 & 2 & 3 & 4 & 5 & 6 & 7 \\
\hline$i$ & MTTF $=x$ & sand $\%=y$ & $x^{2}$ & $x \cdot y$ & $\mathrm{MTTF}_{\text {teor. }}$ & $D$ \\
\hline 1 - Drmno & 1348.13 & 85 & 1817453.58 & 114591.02 & 1352.70 & 4.57 \\
\hline 2 - Ćirikovac & 1808.36 & 54 & 3270151.35 & 97651.22 & 1851.72 & 43.37 \\
\hline 3 - TamnavaZapad & 2073.02 & 41 & 4297415.28 & 84993.85 & 2060.99 & 12.03 \\
\hline 4 - Polje D & 2121.40 & 40 & 4500345.22 & 84856.07 & 2077.09 & 44.31 \\
\hline 5 - Polje B & 2159.16 & 38 & 4661989.73 & 82048.24 & 2109.28 & 49.88 \\
\hline 6 -VelikiCrljeni & 2437.34 & 14 & 5940603.22 & 34122.69 & 2495.62 & 58.29 \\
\hline$\Sigma=$ & 11947.41 & 272 & 24487958.38 & 498263.10 & & \\
\hline
\end{tabular}

\section{Conclusion}

In this paper on the base of theory of reliability and contents of abrasive components in composition of soil, i.e. based on analysis of data on time to failure and the percent of quartz in soil on which bulldozers move, set the model of reliability centered maintenance. It is calculated the mathematical dependency between mean time to failure and percent of quartz (equation 10). This relationship has a linear character (Figure 7), and can serve as a simple and easily applicable criterion for making decisions about the way bulldozers are utilized for the efficient work in the pit. In that sense it is recommended that preventive changes upper roller when reliability is reduced to about $70 \%$, when the expected increase in the intensity of wear.

Equation 10 can serve to predict the mean time in the work of the bulldozers which are analyzed in relation to sand percentage in the soil. Equation covers larger scope of types of soils. Equation also proves the hypothesis of chapter 2 of this article, a large amount of hard components in one of the contact areas contributes to intensive wear and shorter life time of contact elements. Dependence is linear, between life time and content of contact materials. Equation 10 can be used as a base for the implementation of maintenance policy $(\mathrm{RCM})$ regarding the spare parts replacement.

\section{References}

1. Abo-Alkheer AK, El-Hami A, Kharmanda MG, Mouazen AM. Reliability-based design for soil tillage machines. Journal of Terramechanics 2011;48(1): 57-64, http://dx.doi.org/10.1016/j.jterra.2010.06.001.

2. Barabady J, Kumar U. Reliability analysis of mining equipment: A case study of a crushing plant at Jajarm Bauxite Mine in Iran. Reliability Engineering and System Safety 2008; 93(4): 647-653, http://dx.doi.org/10.1016/j.ress.2007.10.006.

3. Bugaric U, Tanasijevic M, Polovina D, Ignjatovic D, Jovancic P. Lost production costs of the overburden excavation system caused by rubber belt failure. Eksploatacja i Niezawodnosc - Maintenance and Reliability 2012; 14(4): 333-341

4. Cerchar - Centre d' Etudes et Recherches de Charbonnages de France, The Cerchar Abrasiveness Index.- 12 S., 1986. Verneuil

5. Chateauneuf A, Cocheteux F, Deffarges F, Sourget F. Reliability analysis of screwed connections in high-speed trains, considering fatigue, corrosion, and imperfect maintenance operations. Proceedings of the Institution of Mechanical Engineers, Part O: Journal of Risk and Reliability September 2011; 225: 293-306, http://dx.doi.org/10.1177/1748006x11402738.

6. Chen SL, Wood RJK, Wang L, Callan R, Powrie HEG. Wear detection of rolling element bearings using multiple-sensing technologies and mixture-model-based clustering method. Proceedings of the Institution of Mechanical Engineers, Part O: Journal of Risk and Reliability June 1, 2008; 222: 207-218, http://dx.doi.org/10.1243/1748006xjrr89.

7. Freeman LJ, Vining GG. Reliability data analysis for life test designed experiments with sub-sampling. Quality and Reliability Engineering International 2013; 29(4): 509-519, http://dx.doi.org/10.1002/qre.1398.

8. Ivanov V, Shyrokau B, Augsburg K, Algin V. Fuzzy evaluation of tyre-surface interaction parameters. Journal of Terramechanics 2010; 47(2): 113-130, http://dx.doi.org/10.1016/j.jterra.2009.08.003.

9. Jaarsveld WV, Dekker R. Spare parts stock control for redundant systems using reliability centered maintenance data. Reliability Engineering and System Safety 2011; 96(11): 1576-1586, http://dx.doi.org/10.1016/j.ress.2011.06.015.

10. Jakobsen PD, Bruland A, Dahl F. Review and assessment of the NTNU/SINTEF Soil Abrasion Test (SAT ${ }^{\text {TM }}$ ) for determination of abrasiveness of soil and soft ground. Tunnelling and Underground Space Technology 2013; 37: 107-114, http://dx.doi.org/10.1016/j.tust.2013.04.003.

11. Jovancic P, Tanasijevic M, Ivezić D. Serbian energy development based on lignite production. Energy Policy 2011; 39(3): 1191-1199, http:// dx.doi.org/10.1016/j.enpol.2010.11.041.

12. Lei Y. Evaluation of three methods for estimating the Weibull distribution parameters of Chinese pine. Journal of Forest Science 2008; 54(12): 566-571.

13. Muro T. Abrasive wear resistance of surface coatings on an excavating tip against a rock mass. Journal of Terramechanics 1985; 22(2): 87-109, http://dx.doi.org/10.1016/0022-4898(85)90145-4.

14. Murthy D.N.P, Xie M, Jiang R. Weibull Models, John Wiley \& Sons, Inc., 2004.

15. NASA Reliability Centered Maintenance Guide for Facilities and Collateral Equipment, February 2000.

16. O'Connor PDT, Kleyner A. Practical Reliability Engineering - Fifth edition. John Wiley \& Sons Ltd., 2012.

17. Peng W, Huang H, Zhang X, Liu Y, Li Y. Reliability based optimal preventive maintenance policy of series-parallel systems. Eksploatacja i Niezawodnosc - Maintenance and Reliability 2009; 42(2): 4-7.

18. Plinninger R., Kasling H, Thuro K, Wear Prediction in Hardrock Excavation Using the Cerchar Abrasiveness Index (CAI); EUROCK 2004 \& 53rd Geomechanics Colloquium. Schubert (ed.), VGE, 2004. Germany, Esse; 599-604.

19. Project "Actualized investment program of construction of surface mine Tamnava West Field" University of Belgrade - Faculty of Mining and Geology, October 2007. Belgrade, Serbia. (In Serbian)

20. Study "The revised long-term program of development of coal mining in Kostolac", University of Belgrade - Faculty of Mining and Geology, December 2006. Belgrade, Serbia. (In Serbian) 
21. Tanasijevic M, Bugaric U, Jovancic P, Ignjatovic D, Polovina D. Relationship between the reliability and the length of conveyor rubber belt. Proceedings of the 29th Danubia-Adria Symposium on Advances in Experimental Mechanics, 26th-29th September 2012. Beograd; 274277. ISBN 978-86-7083-762-1

22. Tanasijevic M, Ivezic D, Jovancic P, Ignjatovic D, Bugaric U. Dependability assessment of open-pit mines equipment - study on the bases of fuzzy algebra rules. Eksploatacja i Niezawodnosc - Maintenance and Reliability 2013; 15(1): 66-74.

23. Thies PR, Johanning L, Smith GH. Assessing mechanical loading regimes and fatigue life of marine power cables in marine energy applications. Proceedings of the Institution of Mechanical Engineers, Part O: Journal of Risk and Reliability February 2012; 226: 18-32, http://dx.doi.org/10.1177/1748006x11413533.

24. Uzgoren N, Elevli S, Elevli B, Uysal O. Reliability analysis of draglines' mechanical failures. Eksploatacja i Niezawodnosc- Maintenance and Reliability 2010; 4(48): 23-28.

25. Wang Z, Huang HZ, Du X. Reliability - based design incorporating several maintenance policies. Eksploatacja i Niezawodnosc - Maintenance and Reliability 2009; 44(4): 37-44.

26. Weibull W. A statistical distribution functions of wide applicability. Journal of Applied Mechanics - Transaction ASME 1951; $18(3)$ : $293-297$.

27. West G. Technical Note - Rock Abrasiveness Testing for Tunnelling. International Journal of Rock Mechanics and Mining Science \& Geomechanics 1989. 26(2): 151-160, http://dx.doi.org/10.1016/0148-9062(89)90003-X.

28. Yaralı O, Yasar E, Bacak G, Ranjith PG. A study of rock abrasivity and tool wear in Coal Measures Rocks, International Journal of Coal Geology 2008; 74: 53-66, http://dx.doi.org/10.1016/j.coal.2007.09.007.

29. Zhang T, Dwight R. Choosing an optimal model for failure data analysis by graphical approach, Reliability Engineering and System Safety 2013; 115: 111-123, http://dx.doi.org/10.1016/j.ress.2013.02.004.

30. Zhou X, Xi L, Lee J. Reliability-centered predictive maintenance scheduling for a continuously monitored system subject to degradation. Reliability Engineering and System Safety 2007; 92(4): 530-534, http://dx.doi.org/10.1016/j.ress.2006.01.006.

\section{Radiša DJURIĆ}

Electric Power Industry of Serbia

Nikole Tesle 5-7

12208 Kostolac, Serbia

Vladimir MILISAVLJEVIĆ

University of Belgrade Faculty of Mining and Geology

Djusina 7, 11000 Belgrde, Serbia

E-mail: djuraisa@gmail.com

vladimir.milisavljevic@rgf.bg.ac.rs 